BIOMEDICAL AND BIOSOCIAL ANTHROPOLOGY
$\begin{gathered}\text { Official Journal of the International Academy } \\ \text { of Integrative Anthropology } \\ \text { journal homepage: http://bba-journal.com }\end{gathered}$

\title{
Histological changes of the adrenal glands vessels after experimental thermal trauma and under the conditions of lyophilized xenoskin use
}

Kulbitska V. V.

I. Horbachevsky Ternopil National Medical University, Ternopil, Ukraine

\section{ARTICLE INFO}

Received: 07 January 2021

Accepted: 11 February 2021

UDC: $616.136 .6 / .146 .3-091.8: 616-$

001.17]-085.324-092.9

\section{CORRESPONDING AUTHOR}

e-mail: kulbitska@tdmu.edu.ua Kulbitska V. V.
Burns, as a stress factor, cause circulatory and microcirculation disorders in the organs. In the scientific literature, the issues of structural reorganization of the vascular bed of the adrenal glands in thermal trauma and under conditions of correction by lyophilized xenoskin are insufficiently covered and therefore require further study. The aim of our study was to study the microscopic changes of the vessels of the adrenal glands in the dynamics after experimental thermal trauma and under conditions of correction. The experiment was performed on adult white male rats. Grade III burn (18$20 \%$ of the skin surface) was applied under thiopental-sodium anesthesia with copper plates heated in water to a temperature of $97-100^{\circ} \mathrm{C}$, on the epilated surface of the skin of the back for 10 seconds. One day after the thermal injury, an early necrectomy was performed and the wound was covered with a substrate of lyophilized xenoskin. Animal decapitation and microscopic changes were studied at days 7, 14, and 21 of injury modeling. The manufacture of histopreparations was carried out according to conventional methods. Histological examinations after experimental thermal trauma and correction of xenoskin substrate on the 7th day showed that already in this period of the experiment there were less pronounced destructive changes in the structure of the vessels of the adrenal glands. Some blood vessels were unevenly filled and dilated. The hemocapillaries of the microcirculatory tract are blood-filled, the vessel wall is destructively altered, and perivascular edema is present. On the 14th day of the experiment, moderately blood vessels were observed. The wall of large vessels is slightly swollen, partially thickened, hemocapillaries are moderately blood-filled, with dilated lumens and continuous endothelial lining. Under the conditions of application of the substrate of lyophilized xenoskin on the 21st day of the experiment, the structural organization of the vascular bed of the adrenal glands was significantly better compared to the previous terms of the study. Most vessels had evenly dilated lumens and moderate blood supply, and wall edema was insignificant. The walls of microvessels are preserved, well structured, endotheliocytes without severe damage, without signs of infiltration and edema. Thus, the results of microscopic examination showed that early necrectomy, and subsequent closure of the wound with a substrate of lyophilized xenoskin, creates optimal conditions for regenerative processes in both burns and vascular bed of the adrenal glands. On the 7th day after the burn and under conditions of correction, the study of the vascular bed of the adrenal glands showed a moderate degree of destructive changes in the vascular bed of the adrenal glands and the initial signs of their regeneration. In the late terms (14-21 days) of the experiment the relative normalization of cellular parenchymal components of the organ was established against the background of restoration of the structural organization of the microcirculatory tract. Key words: histological changes, vessels of the adrenal glands, lyophilized xenoskin, thermal trauma.

\section{Introduction}

It is well known that deep and significant burns, in addition to damage to the skin and surrounding areas, lead to structural reorganization of all organs and systems of the affected organism [2, 4, 10, 22, 24, 30]. Pain shock caused 
by burns causes changes in the endocrine organs, in particular the adrenal glands, which produce a wide range of hormones that control the nature of protective and compensatory processes and mechanisms of adaptation of the body after exposure to this exogenous factor $[5,9,18$, $27,34]$. Burns, as a stress factor, also cause circulatory and microcirculation disorders in the organs, which is manifested in plethora and vasodilation, edema, stasis and subsequent tissue hypoxia [7, 16, 28, 32]. Endogenous intoxication of the body, the source of which is a burn wound, plays a significant role in the pathogenesis of burn injury [1, $11,12,23,25]$. In this regard, as a corrective factor in severe burn injuries used lyophilized xenoskin, in particular, its crushed substrate, which in addition to redox, sorptionantitoxic, plastic and metabolic effects adsorbs a significant amount of burnt skin damaged products. tissues, microorganisms and toxins, preventing the development of infection and positively affecting the morphofunctional state of organs after burns $[8,15,19]$. In the scientific literature, the issues of structural reorganization of the vascular bed of the adrenal glands in thermal trauma and under conditions of correction by lyophilized xenoskin are insufficiently covered and therefore require further study.

The aim of our study was to study the microscopic changes of the vessels of the adrenal glands in the dynamics after experimental thermal trauma and under conditions of correction by the substrate of xenoskin.

\section{Materials and methods}

The experimental study was performed on 30 adult white male rats weighing 160-180 g. Rats were kept in the vivarium of I. Horbachevsky Ternopil National Medical University, Ministry of Health of Ukraine. Animal care and all manipulations were carried out in accordance with the recommendations of the European Convention for the Protection of Vertebrate Animals Used for Experimental and Other Scientific Purposes (Strasbourg, 1986) and in accordance with the provisions of the General Ethical Principles for Animal Experiments adopted by the First National Congress of Bioethics (Kyiv, 2001). The skin burn was applied under thiopental-sodium anesthesia by applying copper plates for 10 seconds, which were previously kept in water with a constant temperature of 97$1000 \mathrm{C}$. The total area of the burn was $18-20 \%$ of the epilated body surface of the animals, which is sufficient for the formation of third-degree burns. 1 day after the experimental thermal injury, necrectomy of the affected areas of the skin was performed and the wound was covered with a crushed substrate of lyophilized xenoskin [21, 26, 33]. Animal decapitation was performed on days 7 , 14 and 21 of the experiment [17]. For histological examination, pieces of the adrenal glands were removed, the tissue was fixed in $10 \%$ neutral formalin solution, dehydrated in alcohols of increasing concentration and poured into paraffin blocks. Sections made on a sled microtome with a thickness of 5-6 $\mu \mathrm{m}$ were stained with hematoxylin-eosin. Morphological studies were performed using a system of visual analysis of histological specimens [13]. To make semi-thin sections (1-2 $\mu \mathrm{m}$ thick), the material was fixed in a $2.5 \%$ solution of glutaraldehyde with a pH of 7.3-7.4. Postfixation was performed with a $1 \%$ solution of osmium tetroxide, followed by its dehydration in alcohols of increasing concentration and poured into a mixture of epoxy resins. Semi-thin sections were made on an LKB-3 ultramicrotome and stained with methylene blue. The images were displayed on a computer monitor from a MICROmed SEO SCAN microscope and photodocumented using a Vision CCD Camera.

\section{Results}

Previous microscopic examinations of the adrenal glands after burn injury revealed significant destructive and degenerative changes in all structural components of the organs, especially in the late stages of the experiment (1421 days). Histological examinations after experimental thermal trauma and application of the substrate of lyophilized xenoskin on the 7th day showed that already in this period of the experiment there were less pronounced destructive changes in the structure of the vessels of the adrenal glands. Small-diameter arteries (Fig. 1A) and arterioles were observed in the connective tissue capsule of the organ, some of which formed plexuses in the subcapsular zone, from which precapillaries intertwined in the surface layers of the glomerulosa zone, entwining endocrinocytes and forming anastomoses. Some arterioles at right angles passed through the cortex and reached the medulla. The wall of the arterioles was destructively altered, their inner elastic membrane in some areas was blurred and intermittent. Plasmalemma of endothelial cells formed a protrusion, and their nuclei protruded into the lumen of the vessel. The middle membrane of the arterioles was thickened, smooth myocytes were hypertrophied, swollen, with hyperchromic nuclei and weakly oxyphilic cytoplasm. The connective tissue elements of the outer adventitial membrane were disorganized, perivascular edema was detected.

In the cortex, some blood vessels were unevenly filled and dilated, and their walls were thickened. Hemocapillaries of the microcirculatory tract had blood-filled lumens, there were accumulations of erythrocytes and other formed elements of blood. Stagnant phenomena were detected in microvessels. Hemorrhages in the glomerulosa and fasciculata zones were isolated. The most pronounced violation of microcirculation was observed in the reticularis zone of the adrenal cortex (Fig. 1B).

Wide lumens of postcapillary venules and central vein of adrenal glands were observed in medulla. Their wall was destructively altered, perivascular edema and leukocyte infiltration of both media and adventitia were observed. Erythrocyte sludges and the phenomenon of leukocyte diapedesis were detected in the venules of the medulla, but excessive thrombosis was not detected. Sinusoidal hemocapillaries of this area were dilated, moderately blood- 

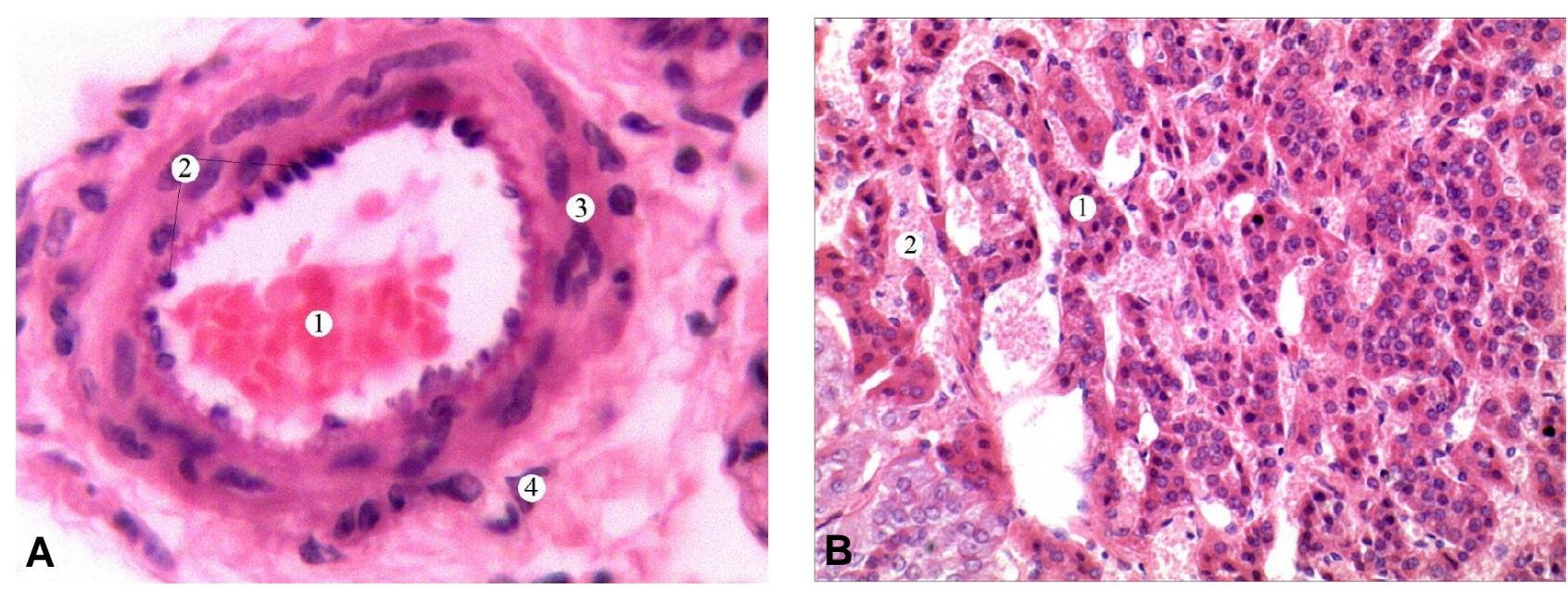

Fig. 1. Histological changes of the adrenal glands on the 7th day after thermal injury in the conditions of application of the substrate of lyophilized xenoskin. A - artery of small diameter. 1 - lumen, 2 - endothelial cell nuclei, 3 - media, 4 - destruction of adventitia. Staining with hematoxylin and eosin. x400. B - fasciculata zone of the adrenal cortex. 1 - endocrineocytes of the fasciculata zone, 2 - blood-filled hemocapillaries. Staining with hematoxylin and eosin. x400.
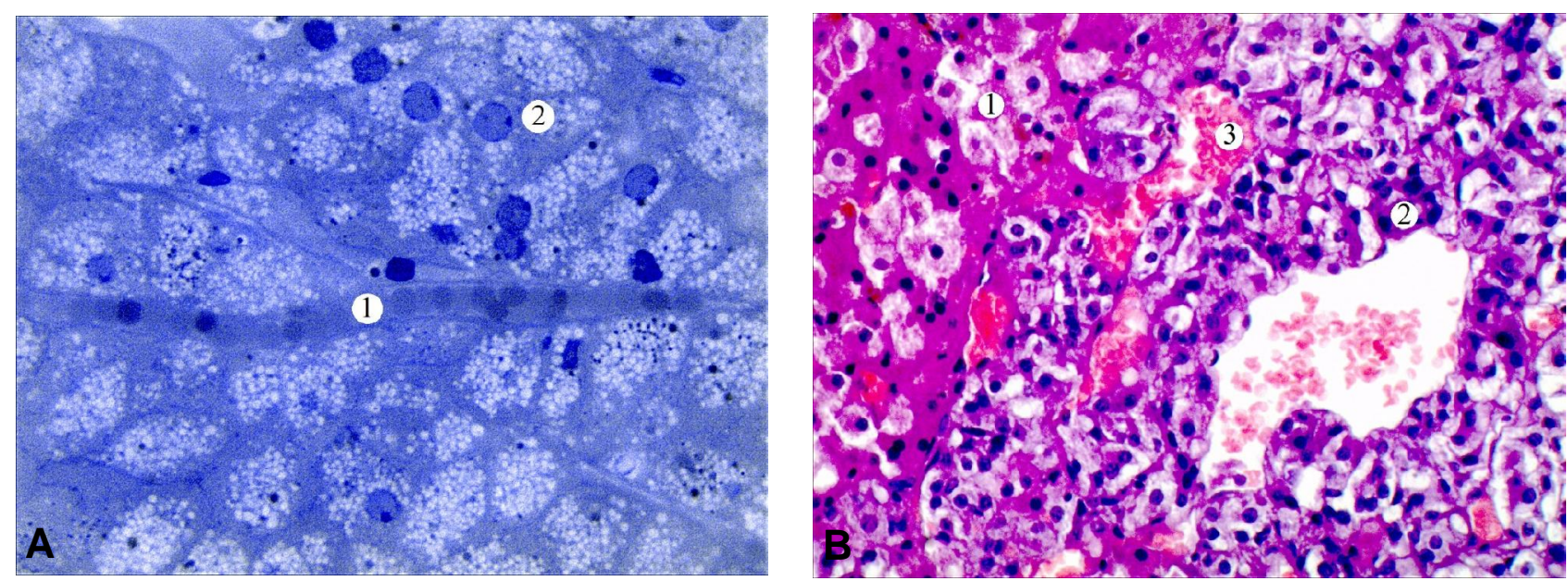

Fig. 2. Microscopic changes of the adrenal glands on the 14th day after thermal trauma under the conditions of correction by the substrate of lyophilized xenoskin. A - hemocapillary of the reticularis zone of the cortex. Methylene blue staining. x400. 1 - erythrocytes in the lumen of the hemocapillary, 2 - endocrinocytes. B - sinusoidal hemocapillaries of the medulla. 1 - endocrinocytes of fasciculate zone, 2 - medulla endocrinocytes, 3 - blood-filled hemocapillaries. Staining with hematoxylin and eosin. x400.

filled, endothelial lining and basement membrane were with moderate destructive changes.

Histological examination of the adrenal glands on the 14th day of the experiment under conditions of correction, moderately blood-filled vessels of the glands were observed. The wall of large vessels of the cortex was slightly swollen, partially thickened, the adventitial membrane was slightly infiltrated with leukocytes and macrophages, its defibering was insignificant. The small-diameter arteries that were present in the capsule of the organ had well-structured membranes.

However, in the wall of the arterioles of the capsule, disorganization of the endothelial lining and thickening or swelling of the basement membrane were sometimes observed. Myocytes of some arterioles did not have clear contours and were disorganized. The adventitial membrane contained a moderate amount of collagen fibers. Precapillary arterioles had small clusters of erythrocytes.

Most venules and veins in the medulla were dilated and blood-filled, but the wall without signs of destruction, with slight edema, in the lumens were mostly erythrocytes. The phenomena of adhesion and diapedesis of leukocytes through the venule wall were rarely detected. In the connective tissue layers of the cortex there were dilated hemocapillaries, which were moderately blood-filled, the wall of which was slightly swollen and infiltrated with leukocytes and macrophages, but the endothelial lining was continuous, without signs of destruction (Fig. 2A). Along with this, the hemocapillaries of the reticularis zone of the cortex were significantly blood-filled. In the medulla at this time of the experiment were mainly observed full-blooded capillaries with dilated lumens and continuous endothelial lining. In the perivascular space, the interstitial edema was insignificant, without signs of diapedetic hemorrhage (Fig. 2B). 

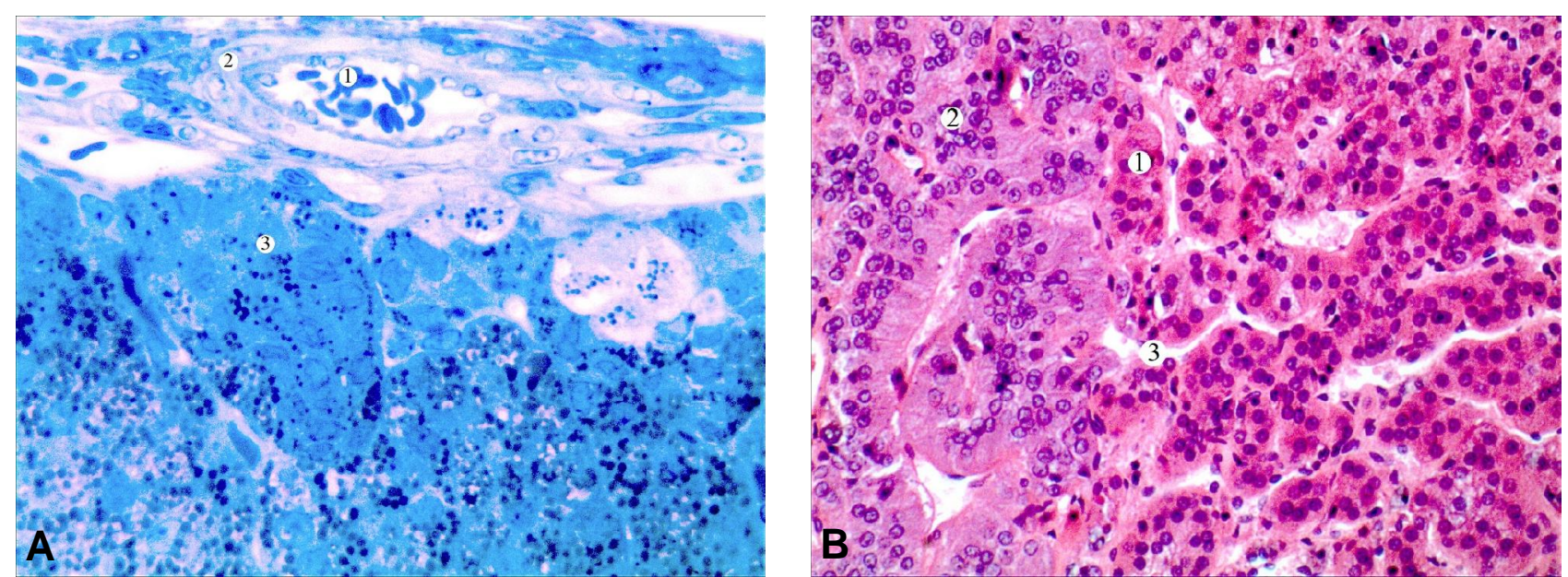

Fig. 3. Microscopic changes of the adrenal glands on 21 day after thermal injury and the use of crushed substrate of lyophilized xenoskin. A - artery of capsule. 1 - blood-filled lumen, 2 - clearly structured wall, 3 - endocrinocytes of glomerulosa zone. Methylene blue staining. x400. B - fragment of the cortex medulla of the adrenal gland. 1 - endocrinocytes of fasciculate zone, 2 - medulla endocrinocytes, 3 - moderately blood-filled hemocapillaries with clear wall contours. Staining with hematoxylin and eosin. $x 400$.

Under the conditions of application of the substrate of lyophilized xenoskin on the 21 st day of the experiment, the structural organization of the vascular bed of the adrenal glands was significantly better compared to the previous terms of the study. Most vessels of the capsule had evenly dilated lumens and moderate blood supply (Fig. 3A). The swelling of the wall was insignificant. Rarely in the wall of the vessels were lymphocyte-infiltrated areas, singly they were present mainly in the adventitia. The vessels of the venous department were characterized by well blood supply, the walls of the venules are slightly thickened, adventitia of vessels with slight edema, almost no infiltration of leukocytes. There were signs of minor destruction of individual endothelial cells. The phenomena of diapedesis and adhesion of leukocytes through the walls of venules were detected singly. Most blood vessels of the cortex microcirculatory tract were moderately blood-filled, the lumens of the capillaries are clearly contoured. The walls of microvessels are preserved, well structured, endotheliocytes without severe damage, the basement membrane is homogeneous, not fluffy, microthrombi were not detected in the lumen of the capillaries. The blood vessels of the medulla also had wide blood-filled lumens. The vessel wall is well structured, without signs of infiltration and edema. Endothelial lining is continuous, perivascular edema is insignificant, diapedetic hemorrhages are absent (fig. 3B).

\section{Discussion}

The adrenal glands as stress-sensitive organs of the endocrine system have a significant impact on the development of adaptation mechanisms in the body after exposure to various stressful exogenous and endogenous factors [3, 35]. Thus, the results of our microscopic studies of the vascular bed of the adrenal glands after burn injury and subsequent correction of the substrate of lyophilized xenoskin in both cortex and medulla at the beginning of the experiment showed manifestations of increased functional activity, which is a characteristic feature of general adaptive syndrome. stress. There was a pronounced arterial spasm and dilatation of the venous component of the vascular bed of the adrenal glands, edema and endothelial detachment, significant deformation of the inner elastic membrane with simultaneous swelling of their middle membrane, which is somewhat consistent with research by other scientists. Similar changes were observed by the author [6] in the early stages of exposure to the cold factor with the simultaneous use of stress-protective drugs, and identically to our studies in the late stages showed signs of stabilization of the structural organization of the vascular bed of the body. Dilation of microvessels, edema of their walls and vessels with endothelial destruction are solitary. At all stages of the experiment as a result of exposure to both burn and cold trauma in the lumen of the hemocapillaries of all areas accumulation of blood cells was observed. Diapedesis of leukocytes and macrophages is characterized by the action of both cold factor [6] and the effect of thermal trauma on the adrenal gland, which we studied, indicates an active process of elimination of damaged and destroyed cells, and existing lymphocytic infiltration causes the possible development of autoimmune. Study of morphofunctional reorganization of the adrenal glands under long-term exposure to heavy metal salts and subsequent non-hormonal correction [14], reorganization of the vascular bed of the body in acute peritonitis and correction by cryopreserved placenta [29], data on the systematic effects of hypergravity on the background of glutargin microcirculatory tract of the body in experimental diabetes mellitus and its correction by exenatide [31] had a similar dynamics of changes that occurred in the simulation of thermal trauma and its correction, as the adrenal glands are the target organ for toxic substances, and intoxication is characteristic of stress. 
In particular, the vessels of the capsule are usually dilated, full-blooded, the structure of the walls of some arteries and arterioles is destructively altered: the endothelial layer and muscle are thickened, there was erythrocyte stasis, intertrabecular hemocapillaries of the zona glomerulosa appeared optically empty. Zona fasciculate and reticularis contained dilated vessels filled with blood cells. According to researchers $[14,20,29,31]$, in the organ there are signs of impaired permeability of the vascular wall and the release of cellular elements of blood and plasma into the extravascular space in the initial stages of the study. The use of corrective factors in the late stages of the experiment under long-term exposure to various exogenous and endogenous factors and subsequent correction showed a significant stress-protective effect on the structural components of vascular walls, reduces the manifestations of general adaptation syndrome, but does not fully restore the morphofunctional state of the organ and its vessels.

Thus, at different terms of research under the influence of exogenous and endogenous factors and subsequent correction, the vessels of the adrenal glands undergo the same type of changes, which indicates the active participation of the adrenal glands in regenerative processes in the body. In general, the hemodynamics of the organ is usually subject to gradual normalization, but the degree of restoration of the structural organization of the vessel walls of the organ is directly dependent on the duration of the experiment and the duration of the corrective factor. blood and residual effects of negative toxic effects on the body of factors of exogenous and endogenous origin.

\section{References}

[1] Ahmad, A., Herndon D. N., \& Szabo C. (2019). Oxandrolone protects against the development of multiorgan failure, modulates the systemic inflammatory response and promotes wound healing during burn injury. Burns, 45(3), 671-681. doi: 10.1016/..burns.2018.10.006

[2] Arbuthnot, M. K., \& Garcia, A. V. (2019). Early resuscitation and management of severe pediatric burns. Seminars in pediatric surgery, 28(1), 73-78. doi: 10.1053/j.sempedsurg.2019.01.013

[3] Bali, A., \& Jaggi, A. S. (2015). Preclinical experimental stress studies: Protocols, assessment and comparison. European journal of pharmacology, (746), 282-292. doi: 10.1016/ j.ejphar.2014.10.017

[4] Barrett, L. W., Fear, V. S., Waithman, J. C., Wood, F. M., \& Fear, M. W. (2019). Understanding acute burn injury as a chronic disease. Burns \& Trauma, (7), 23. doi: 10.1186/s41038-019-0163-2

[5] Berger, I., Werdermann, M., Bornstein, S. R., \& Steenblock, C. (2019). The adrenal gland in stress - adaptation on a cellular level. The journal of steroid biochemistry and molecular biology, (190), 198-206. doi: 10.1016/j.jsbmb.2019.04.006

[6] Bondarev, Ye. V., Shtrygol, S. Yu., \& Laryanovskaya, Yu. B. (2018). Стреспротекторна дія препаратів глюкозаміну та ацетилсаліцилової кислоти за умов гострої загальної холодової травми [Stress-protective effect of glucosamine preparations and acetylsalicylic acid in acute general cold injury]. Фармакологія та лікарська токсикологія - Pharmacology and Drug Toxicology, (6), 34-43.

[7] Comish, P. B., Carlson, D., Kang, R., \& Tang, D. (2020). Damage-
Further research is planned to determine the morphological condition of the vessels of the adrenal glands in thermal injury and the use of other corrective drugs in the experiment.

\section{Conclusion}

1. The results of microscopic examination showed that early necrectomy, removal of necrotic tissue and subsequent closure of the wound with crushed substrate of lyophilized xenoskin as a corrective factor, creates optimal conditions for regenerative processes in both burns and vascular bed of the adrenal glands.

2. On the 7th day after the burn and under conditions of correction, the study of the vascular bed of the adrenal glands showed a moderate degree of destructive changes in the components of the vascular bed of the adrenal glands and the initial signs of their regeneration. The studied vessels had a slightly dilated lumen, moderate blood supply and edema of the vascular wall, single leukocyte infiltrates.

3 . In the late terms (14-21 days) of the experiment with the use of a corrective factor established the relative normalization of cellular parenchymal components of the body on the background of restoring the structural organization of the microcirculatory tract, indicating the active regenerative processes in the body. The blood supply of large-diameter vessels was restored, moderate, the wall was clearly contoured, without signs of edema, general infiltration and sclerosis, which indicates the restoration of their structure and, accordingly, the blood supply to the adrenal glands.

associated molecular patterns and the systemic immune consequences of severe thermal injury. The journal of immunology, 205(5), 1189-1197. doi: 10.4049/jimmunol.2000439

[8] Costa, B. A., Junior, E. M. L., de Moraes Filho, M. O., Fechine, F. V., de Moraes, M. E. A., Junior, F. R. S., \& Rocha, M. B. S. (2019). Use of tilapia skin as a xenograft for pediatric burn treatment: $A$ case report. Journal of burn care \& research, 40(5), 714-717. doi: $10.1093 / \mathrm{jbcr} / \mathrm{irz} 085$

[9] Di Lorenzo, M., Barra, T., Rosati, L., Valiante, S., Capaldo, A., De Falco, M., \& Laforgia, V. (2020). Adrenal gland response to endocrine disrupting chemicals in fishes, amphibians and reptiles: a comparative overview. General and Comparative Endocrinology, 1(297), 113550. doi: 10.1016/j.ygcen.2020.113550

[10] Greenhalgh, D. G. (2019). Management of Burns. New England journal of medicine, 380(24), 2349-2359. doi: 10.1056/ nejmra1807442

[11] Hew, J., Parungao, R., Shi, H., Tsai, K., Kim, S., Ma, D., ... \& Wang, Y. (2020). Mouse models in burns research: Characterisation of the hypermetabolic response to burn injury. Burns, 46(3), 663-674. doi: 10.1016/j.burns.2019.09.014

[12] Hicks, K. E., Huynh, M. N. Q., Jeschke, M., \& Malic, C. (2019). Dermal regenerative matrix use in burn patients: A systematic review. Journal of plastic, reconstructive \& aesthetic surgery, 72(11), 1741-1751. doi: 10.1016/j.bjps.2019.07.021

[13] Horalskyi, L. P., Khomych, V. T., \& Kononskyi, O. I. (2005). Основи гістологічної техніки та морфоорункціональних методів дослідження в нормі та при патології 
[Fundamentals of histological technique and morphofunctionalmethods of research in normal and pathology]. Державний агроекологічний університет - State Agroecological University. Житомир: Полісся - Zhytomyr: Polissya.

[14] Hryntsova, N. B., Romaniyk, A. M., \& Bumeister, V. I. (2019). Морфологічні перебудови кіркової речовини наднирників щурів за умов довготривалого впливу солей важких металів та негормональної корекції [Morphological rearrangements of the rat's adrenal cortex under conditions of prolonged exposure to heavy metal salts and non-hormonal correction]. Морфологія - Morphologia, 13(3), 26-31. doi: 10.26641/1997-9665.2019.3.26-31

[15] Kalsi, R., Messner, F., \& Brandacher, G. (2020). Skin xenotransplantation: technological advances and future directions. Current opinion in organ transplantation, 25(5), 464476. doi: $10.1097 /$ mot.0000000000000798

[16] Knyazevich-Chorna, T. V., Mikhailyuk, I. O., Rudyak, A. N., \& Tarasevych, N. R. (2019). Функціональний стан надниркових залоз в поєднанні з їх морфологічною перебудовою на різних етапах постгіпотермічного періоду [Functional state of the adrenal glands with combination of their morphological reorganization at different stages of a posthypothermic period]. Вісник Вінницького Національного Медичного Універсиmemy - Reports of Vinnytsia National Medical University, 1(23), 41-45. doi: 10.31393/reports-vnmedical-2019-23(1)-06

[17] Korytskyi, V. G., Nebesna, Z. M., \& Kramar, S. B. (2019). Restructuring of vessels of the thyroid gland after experimental thermal injury along with application of minced substrate of freeze-dried xenograft. World of medicine and biology, 2(68), 183-187. doi: 10.26724/2079-8334-2019-2-68-183-187

[18] Kozhemyakin, Yu. M., Chromov, O. S., \& Filonenko, M. A. (2017). Науково-практичні рекомендації з утримання лабораторних тварин та роботи з ними [Scientific and practical recommendations for the care and use of laboratory animals]. Київ: Інтерсервіс - Kiev: Interservis.

[19] Manukhina, E. B., Tseilikman, V. E., Tseilikman, O. B., Komelkova, M. V., Kondashevskaya, M. V., Goryacheva, A. V., ... \& Downey, H. F. (2018). Intermittent hypoxia improves behavioral and adrenal gland dysfunction induced by post-traumatic stress disorder in rats. Journal of applied physiology, 125(3), 931937. doi: 10.1152/japplphysiol.01123.2017

[20] Masson-Meyers, D. S., Andrade, T. A. M., Caetano, G. F., Guimaraes, F. R., Leite, M. N., Leite, S. N., \& Frade, M. A. C. (2020). Experimental models and methods for cutaneous wound healing assessment. International journal of experimental pathology, (1-2), 21-37. doi: 10.1111/iep. 12346

[21] Moroz, G. А. (2012). Структурнофункціональні зміни у надниркових залозах 12-місячних щурів при систематичному гіпергравітаційному впливі та на фроні застосування глутаргіну [Structural and functional changes in the twelve-monthold rat's suprarenal glands on systematic exposure to hypergravity and under use of glutargin]. Світ медицини та біології - World Of Medicine and Biology, (3), 43-47.

[22] Nahaichuk, V. I., Khimich, S. D., Zheliba, M. D., Zhuchenko, O. P., Povoroznyk, A. M., Prysiazhniuk, M. B., \& Chornopyshchuk, R. M. (2017). Сучасні технології лікування хворих з критичними та надкритичними опіками [Modern technologies of treatment of patients with critical and supravithic burns]. Вісник Вінницького національного медичного унівеситету - Reports of Vinnytsia National Medical University, 2(21), 428-433.

[23] Ogura, A., Tsurumi, A., Que, Y. A., Almpani, M., Zheng, H.,
Tompkins, R. G., ... \& Rahme, L. G. (2019). Associations between clinical characteristics and the development of multiple organ failure after severe burns in adult patients. Burns, 45(8), 1775-1782. doi: 10.1016/j.burns.2019.02.014

[24] Palmieri, T. L. (2020). Transfusion and infections in the burn patient. Surgical infections, 22(1), 49-53. doi: 10.1089/ sur.2020.160

[25] Partain, K. P., Fabia, R., \& Thakkar, R. K. (2020). Pediatric burn care. Current opinion in pediatrics, 32(3), 405-410. doi: 10.1097/ mop.0000000000000902

[26] Pielesz, A., Gawlowski, A., Binias, D., Bobinski, R., Kawecki, M., Sama, E., \& Waksmanska, W. (2019). A histologic perspective on electrical and thermal burn-injured human skin. Advances in skin \& wound care, 32(5), 1-7. doi: 10.1097/ 01.asw.0000554446.59743.9f

[27] Pyatnytsky, O. Yu., Yakovleva, L. V., \& Koshova, O. Y. (2013). Експериментальне дослідження фармакологічних властивостей субстрату кріоконсервованої шкіри свині [Experimental study of pharmacological properties of the cryopreserved swine skin substrate]. Клін. Фармація - Clin. pharm., 17(1), 56-62.

[28] Roshangar, L., Soleimani Rad, J., Kheirjou, R., Reza Ranjkesh, M., \& Ferdowsi Khosroshahi, A. (2019). Skin burns: Review of molecular mechanisms and therapeutic approaches. Wounds, 31(12), 308-315. doi: 10.1038/s41572-020-0145-5

[29] Shaw, P., Sharma, A. K., Kalonia, A., \& Shukla, S. K. (2019). Vascular perfusion: A predictive tool for thermal burn injury. Journal of tissue viability, 29(1), 48-50. doi: 10.1016/ j.jtv.2019.12.002

[30] Skotarenko, Т. А. (2015). Сучасні погляди на морфофункціональний стан наднирників в нормі, при гострому запаленні та можливості впливу на них фетоплацентарних тканин [Current views of morphofunctional state of adrenal glands in normal condition, in acute inflammation, and possible influence on them by placental tissues]. Вісник ВДНзу "Українська медична стоматологічна академія" - Bulletin of Ukrainian Medical Stomatological Academy, 15(2(50)), 237-241.

[31] Tejiram, S., Romanowski, K. S., \& Palmieri, T. L. (2019). Initial management of severe burn injury. Current opinion in critical care, 25(6), 647-652. doi: 10.1097/mcc.0000000000000662

[32] Tkachuk, Yu. L. (2016). Морфологічнахарактеристика судин гемомікроциркуляторного русла кори надниркових залоз при цукровому діабеті та його корекції [Morphological characteristics of microvascular bed in adrenal cortex under diabetes mellitus and under its correction]. Актуальні проблеми сучасної медицини - Actual Problems of the Modern Medicine, 16(1), 245-248.

[33] Torres, M. J. M., Peterson, J. M., \& Wolf, S. E. (2020). Detection of infection and sepsis in burns. Surgical Infections, 22(1), 2027. doi: $10.1089 /$ sur.2020.348

[34] Tsymbalyuk, A. V., Guda, N. V., \& Kyryk, O. О. (2013). Використання подрібненого субстрату ліофілізованого ксенодермоімплантата для місцевого лікування опікових хворих 3 інфрікованими ранами III-IV ступенів [The use of crushed substrate of lyophilized xenograft skin substrate for local treatment of burn patients with infected wounds of III-IV degrees]. Шпитальна хірургія - Hospital Surgery, (1), 81-4.

[35] Zhang, Q.-H., Hao, J.-W., Xiao-Jing, J., Guang-Lei, L., Zhou, M., \& Yao, Y.-M. (2019). Long-lasting neurobehavioral alterations in burn-injured mice resembling post-traumatic stress disorder in humans. Experimental neurology, (323), 113084. doi: 10.1016/j.expneurol.2019.113084 